\title{
Marcin Spychala
}

Uniwersytet Ekonomiczny w Poznaniu

e-mail: marcin.spychala@ue.poznan.pl

\section{ZRÓŻNICOWANIE ROZWOJU \\ SPOLECZNO-GOSPODARCZEGO W POWIATACH WOJEWÓDZTWA WIELKOPOLSKIEGO \\ DIFFERENTIATION OF THE SOCIO-ECONOMIC DEVELOPMENT IN THE DISTRICTS OF THE WIELKOPOLSKA VOIVODESHIP}

DOI: $10.15611 /$ pn.2017.487.26

JEL Classification: O47, O11, O20

Streszczenie: W opracowaniu określono poziom rozwoju społeczno-gospodarczego powiatów województwa wielkopolskiego na podstawie 53 wskaźników ujętych w ramach 5 czynników rozwoju regionalnego: kapitału ludzkiego, kapitału społecznego, kapitału materialnego, kapitału finansowego oraz innowacyjności. Celem artykułu jest przedstawienie zróżnicowania przestrzennego poziomu rozwoju społeczno-gospodarczego województwa wielkopolskiego w układzie powiatów. Poziom rozwoju społeczno-gospodarczego oraz poziom rozwoju jego czynników zostanie określony na podstawie miernika syntetycznego ukazującego odległość taksonomiczną danego powiatu od przyjętego wzorca rozwoju. W artykule postanowiono zweryfikować hipotezę, według której rozwój społeczno-gospodarczy w powiatach województwa wielkopolskiego jest mocno zróżnicowany, a najwyższy jego poziom odnotowuje się w dużych miastach regionu - Poznaniu, Lesznie, Kaliszu i Koninie.

Słowa kluczowe: miernik syntetyczny, redukcja Hellwiga, odległość od wzorca.

Summary: The article presents differentiation of the socio-economic development in the districts of the Wielkopolska Voivodeship. The level of development has been determined on the basis of synthetic measure showing the distance of the district from the adopted model of development resulting from the reduction of the output characteristics by a special Hellwig's method. The article verifies the hypothesis that socio-economic development in the districts of the Wielkopolska Voivodeship is highly diversified, and its highest level is recorded in the largest cities.

Keywords: synthetic indicator, Hellwig's reduction, distance from the model. 


\section{Wstęp}

Określenie stanu oraz perspektyw rozwoju społeczno-gospodarczego jest ważnym problemem badawczym zarówno w teorii ekonomii, jak też w praktyce gospodarczej. Od poziomu rozwoju regionalnego zależy chociażby maksymalna intensywność pomocy publicznej udzielanej w poszczególnych regionach czy też wysokość alokacji funduszy Unii Europejskiej udostępnianej w województwach [Spychała 2016]. Badanie istoty procesu rozwoju społeczno-gospodarczego, jego przyczyn oraz konsekwencji, stanowi przedmiot wielu prac [Barro, Sala-i-Martin 2004; Grosse 2004; Iyer, Kitson, Toh 2005; Stiglitz 2004]. Charakterystyczną cechą tego rozwoju jest bowiem jego zróżnicowanie w układzie regionalnym [Churski 2008]. Wzrastający poziom zróżnicowania rozwoju regionalnego jest jednym z kluczowych problemów współczesnej gospodarki, natomiast podstawowym celem unijnej polityki spójności jest dążenie do niwelowania różnic w poziomie rozwoju regionów Unii Europejskiej.

W opracowaniu określono poziom rozwoju społeczno-gospodarczego na podstawie 53 wskaźników ujętych w ramach 5 czynników rozwoju regionalnego: kapitału ludzkiego, kapitału społecznego, kapitału materialnego, kapitału finansowego oraz innowacyjności. Celem artykułu jest przedstawienie zróżnicowania przestrzennego poziomu rozwoju społeczno-gospodarczego województwa wielkopolskiego w układzie powiatów. Poziom rozwoju społeczno-gospodarczego oraz poziom rozwoju jego czynników zostanie określony na podstawie miernika syntetycznego ukazującego odległość taksonomiczną danego powiatu od przyjętego wzorca rozwoju.

W artykule postanowiono zweryfikować hipotezę, według której rozwój społeczno-gospodarczy w powiatach województwa wielkopolskiego jest mocno zróżnicowany, a najwyższy jego poziom odnotowuje się w miastach na prawach powiatu - Poznaniu, Lesznie, Kaliszu i Koninie. Badaniem objęte zostały wszystkie powiaty województwa wielkopolskiego - łącznie 35 jednostek.

\section{Procedura badawcza}

W celu zbadania poziomu rozwoju społeczno-gospodarczego powiatów województwa wielkopolskiego posłużono się syntetycznym miernikiem odległości od wzorca. Procedurę badawczą przeprowadzono równolegle - w ujęciu statycznym (na podstawie wartości wskaźników w 2015 roku) oraz w ujęciu dynamicznym (na podstawie zmiany wartości wskaźników w latach 2007-2015). Procedura badawcza składała się z czterech etapów: (1) dobór zmiennych - konstrukcja macierzy informacji geograficznej, (2) redukcja przestrzeni wielocechowej, (3) wyznaczenie poziomu rozwoju społeczno-gospodarczego, (4) klasyfikacja powiatów na skali poziomu rozwoju społeczno-gospodarczego. 
Tabela 1. Mierniki uwzględnione w analizie charakteryzujące czynniki rozwoju regionalnego

\begin{tabular}{|c|c|}
\hline Czynnik rozwoju & Mierniki \\
\hline Kapitał ludzki & $\begin{array}{l}\text { przyrost naturalny na } 1000 \text { mieszkańców; saldo migracji na } 1000 \text { mieszkańców; } \\
\text { współczynnik feminizacji ogółem; współczynnik feminizacji ludności w wieku } \\
\text { produkcyjnym; udział osób w wieku produkcyjnym w ludności ogółem; udział } \\
\text { osób w wieku poprodukcyjnym w ludności ogółem; udział osób w wieku przed- } \\
\text { produkcyjnym w ludności ogółem; ludność w wieku nieprodukcyjnym na } 100 \\
\text { osób w wieku produkcyjnym; ludność w wieku poprodukcyjnym na } 100 \text { osób } \\
\text { w wieku przedprodukcyjnym; zdawalność matur w liceach ogólnokształcących; } \\
\text { współczynnik skolaryzacji netto szkół podstawowych; stopa bezrobocia reje- } \\
\text { strowanego; udział bezrobotnych z wykształceniem wyższym w ogólnej liczbie } \\
\text { bezrobotnych; udział bezrobotnych poniżej } 25 \text {. roku życia w ogólnej liczbie bez- } \\
\text { robotnych }\end{array}$ \\
\hline Kapitał społeczny & $\begin{array}{l}\text { frekwencja w I turze wyborów prezydenckich; frekwencja w wyborach parla- } \\
\text { mentarnych; frekwencja w wyborach samorządowych; liczba fundacji, stowa- } \\
\text { rzyszeń i organizacji społecznych na } 1000 \text { mieszkańców; liczba członków kół, } \\
\text { klubów i grup artystycznych na } 1000 \text { mieszkańców; liczba osób fizycznych pro- } \\
\text { wadzących działalność gospodarczą na } 1000 \text { mieszkańców; udział mikroprzed- } \\
\text { siębiorstw wśród wszystkich przedsiębiorstw }\end{array}$ \\
\hline $\begin{array}{l}\text { Kapitał } \\
\text { materialny }\end{array}$ & $\begin{array}{l}\text { długość dróg gminnych i powiatowych o twardej nawierzchni na } 100 \mathrm{~km}^{2} \text {; długość } \\
\text { dróg gminnych i powiatowych o twardej nawierzchni na } 10000 \text { ludności; udział } \\
\text { korzystających z instalacji wodociągowej w ogólnej liczbie ludności; udział ko- } \\
\text { rzystających z instalacji kanalizacyjnej w ogólnej liczbie ludności; udział ko- } \\
\text { rzystających z instalacji gazowej w ogólnej liczbie ludności; udział korzystają- } \\
\text { cych z oczyszczalni ścieków w ogólnej liczbie ludności; odpady wytworzone na } \\
1 \text { km² powierzchni; udział obszarów prawnie chronionych w powierzchni ogó- } \\
\text { łem; emisja zanieczyszczeń pyłowych na } 1 \mathrm{~km}^{2} \text { powierzchni; księgozbiór biblio- } \\
\text { tek na } 1000 \text { mieszkańców; zwiedzający muzea na } 10000 \text { mieszkańców; odsetek } \\
\text { dzieci objętych opieką w żłobkach; odsetek dzieci w placówkach wychowania } \\
\text { przedszkolnego; liczba łóżek w szpitalach ogólnych na } 10000 \text { mieszkańców; } \\
\text { liczba lekarzy na } 10000 \text { mieszkańców }\end{array}$ \\
\hline Kapitał finansowy & $\begin{array}{l}\text { dochody ogółem JST per capita; dochody własne JST per capita; dochody z } \\
\text { podatku od nieruchomości per capita; wydatki ogółem JST per capita; wydatki } \\
\text { majątkowe JST per capita; wydatki na obsługę długu publicznego JST per ca- } \\
\text { pita; saldo budżetu JST per capita; przeciętne miesięczne wynagrodzenie brutto }\end{array}$ \\
\hline Innowacyjność & $\begin{array}{l}\text { udział podmiotów sektora prywatnego w podmiotach gospodarczych ogółem; } \\
\text { udział spółek zagranicznych w podmiotach gospodarczych ogółem; liczba mi- } \\
\text { kroprzedsiębiorstw na } 1000 \text { mieszkańców; liczba dużych przedsiębiorstw na } \\
1000 \text { mieszkańców; udział podmiotów prowadzących działalność usługową w } \\
\text { podmiotach gospodarczych ogółem; udział podmiotów prowadzących działal- } \\
\text { ność finansową w podmiotach gospodarczych ogółem; udział podmiotów pro- } \\
\text { wadzących działalność edukacyjną w podmiotach gospodarczych ogółem; udział } \\
\text { pracujących w przemyśle i budownictwie w pracujących ogółem; udział pracują- } \\
\text { cych w usługach w pracujących ogółem }\end{array}$ \\
\hline
\end{tabular}

Źródło: opracowanie własne na podstawie przeprowadzonego badania. 
W pierwszym etapie procedury badawczej zbudowano macierz informacji geograficznej na podstawie 53 wskaźników, które określały poziom rozwoju oraz jego zmiany w odniesieniu do kapitału ludzkiego, kapitału społecznego, kapitału materialnego, kapitału finansowego oraz innowacyjności (tabela 1). Następnie obliczono współczynniki korelacji liniowej Pearsona między wszystkimi badanymi wskaźnikami wyjściowymi osobno zarówno dla roku 2015, jak i dla ich zmiany w latach 2007-2015. Zmienne, które zostaną ostatecznie wybrane do miernika syntetycznego, powinny być bowiem słabo skorelowane między sobą, aby ich pojemność informacyjna była różna.

Stworzone macierze korelacji liniowej Pearsona były podstawą do przeprowadzenia redukcji zmiennych wyjściowych metodą Z. Hellwiga - wyodrębnienia cech diagnostycznych, czyli tych wskaźników, które zostaną uwzględnione w dalszej procedurze badawczej [Omiotek, Wójcik 2014]. Metoda redukcji cech Z. Hellwiga wykorzystuje do obliczeń współczynniki korelacji między zmiennymi. W metodzie redukcji cech $Z$. Hellwiga za cechę diagnostyczną uznaje się ten wskaźnik, którego suma wartości bezwzględnych współczynników korelacji z pozostałymi cechami jest najwyższa (nazywana jest ona wówczas cechą centralną). Następnie eliminuje się te cechy, dla których wartość współczynnika korelacji z cechą diagnostyczną jest wyższa od wartości krytycznej określonej na podstawie poniższego wzoru [Frank, Todeschini 1994]:

$$
r^{*}=\sqrt{\frac{\left(t^{*}\right)^{2}}{n-2+\left(t^{*}\right)^{2}}},
$$

gdzie: $r^{*}$ - wartość krytyczna współczynnika korelacji; $t^{*}$ - wartość statystyki $t$-Studenta (przyjęto poziom istotności $p=0,05) ; n$ - liczba wskaźników wyjściowych.

$\mathrm{W}$ rezultacie przeprowadzonej metody eliminowane są te cechy, które są istotnie statystycznie skorelowane z cechą diagnostyczną (nazywane cechami satelitarnymi). W każdym kolejnym kroku następuje redukcja macierzy korelacji o cechę centralną i cechy satelitarne. Metodę Z. Hellwiga powtarza się, otrzymując nowe zredukowane macierze korelacji, aż do momentu wyczerpania zbioru cech bądź wyodrębnienia cech izolowanych [Koop 2014; Maddala 2013]. Procedurę przeprowadzono sześciokrotnie: oddzielnie dla poziomu rozwoju społeczno-gospodarczego oraz dla poziomu rozwoju każdego z pięciu kapitałów będących czynnikami rozwoju regionalnego. W tabeli 2 przedstawiono wyniki zastosowania powyższej metody.

Tabela 2. Struktura zmiennych wykorzystanych w badaniu

\begin{tabular}{|l|l|c|c|}
\hline \multicolumn{2}{|c|}{ Poziom badania } & Liczba cech wyjściowych & Liczba cech po redukcji \\
\hline \multicolumn{2}{|c|}{1} & 2 & 3 \\
\hline \multirow{2}{*}{ Kapitał ludzki } & 2015 rok & 14 & 4 \\
\cline { 2 - 4 } & zmiana 2007-2015 & 14 & 9 \\
\hline
\end{tabular}




\begin{tabular}{|l|l|c|c|}
\hline \multicolumn{2}{|c|}{1} & 2 & 3 \\
\hline \multirow{2}{*}{ Kapitał społeczny } & 2015 rok & 7 & 5 \\
\cline { 2 - 4 } & zmiana 2007-2015 & 7 & 7 \\
\hline \multirow{2}{*}{ Kapitał materialny } & 2015 rok & 15 & 6 \\
\cline { 2 - 4 } & zmiana 2007-2015 & 15 & 4 \\
\hline \multirow{2}{*}{ Kapitał finansowy } & 2015 rok & 8 & 5 \\
\cline { 2 - 4 } & zmiana 2007-2015 & 8 & 5 \\
\hline \multirow{2}{*}{ Innowacyjność } & 2015 rok & 9 & 8 \\
\cline { 2 - 4 } & zmiana 2007-2015 & 9 & 6 \\
\hline \multirow{2}{*}{$\begin{array}{l}\text { Poziom rozwoju społecz- } \\
\text { no-gospodarczego }\end{array}$} & 2015 rok & 53 & 11 \\
\cline { 2 - 4 } & zmiana 2007-2015 & 53 & \\
\hline
\end{tabular}

Źródło: opracowanie własne na podstawie przeprowadzonego badania.

W następnym kroku postępowania badawczego wyznaczono wzorzec i antywzorzec rozwoju. Za wzorzec uznano maksymalne wartości standaryzowane poszczególnych cech diagnostycznych, natomiast za antywzorzec - ich wartości minimalne. W kolejnym etapie wyznaczono odległość taksonomiczną każdego powiatu od wzorca na podstawie poniższego wzoru [Nowak 1990]:

$$
d_{i 0}=\sqrt{\sum_{j=1}^{m}\left(z_{i j}-z_{0 j}\right)^{2}},
$$

gdzie: $d_{i 0}$ - odległość powiatu $i$ od wzorca rozwoju; $z_{i j}$ - wartość standaryzowana cechy $j$ dla powiatu $i ; z_{0 j}$ - wartość standaryzowana cechy $j$ dla wzorca rozwoju.

Tabela 3. Macierz wskaźników syntetycznych dla zmiennych w 2015 roku oraz w latach 2007-2015

\begin{tabular}{|l|c|c|c|c|c|c|c|c|c|c|c|c|}
\hline \multirow{4}{*}{ Powiat } & \multicolumn{2}{|c|}{$\begin{array}{c}\text { Kapitał } \\
\text { ludzki }\end{array}$} & \multicolumn{2}{c|}{$\begin{array}{c}\text { Kapitał } \\
\text { społeczny }\end{array}$} & \multicolumn{2}{c|}{$\begin{array}{c}\text { Kapitał } \\
\text { materialny }\end{array}$} & \multicolumn{2}{c|}{$\begin{array}{c}\text { Kapitał } \\
\text { finansowy }\end{array}$} & \multicolumn{2}{c|}{ Innowacje } & \multicolumn{2}{c|}{ Ogółem } \\
\cline { 2 - 18 } & 2015 & $07-15$ & 2015 & $07-15$ & 2015 & $07-15$ & 2015 & $07-15$ & 2015 & $07-15$ & 2015 & $07-15$ \\
\hline \multicolumn{1}{c|}{1} & 2 & 3 & 4 & 5 & 6 & 7 & 8 & 9 & 10 & 11 & 12 & 13 \\
\hline Chodzieski & 0,57 & 0,47 & 0,21 & 0,22 & 0,41 & 0,37 & 0,51 & 0,58 & 0,38 & 0,36 & 0,25 & 0,52 \\
\hline $\begin{array}{l}\text { Czarnkowsko- } \\
\text {-trzcianecki }\end{array}$ & 0,69 & 0,52 & 0,18 & 0,24 & 0,39 & 0,41 & 0,41 & 0,44 & 0,34 & 0,44 & 0,25 & 0,37 \\
\hline Gnieźnieński & 0,67 & 0,48 & 0,24 & 0,23 & 0,47 & 0,44 & 0,41 & 0,36 & 0,37 & 0,35 & 0,43 & 0,37 \\
\hline Gostyński & 0,71 & 0,59 & 0,23 & 0,39 & 0,43 & 0,32 & 0,35 & 0,52 & 0,33 & 0,36 & 0,32 & 0,45 \\
\hline Grodziski & 0,79 & 0,60 & 0,14 & 0,31 & 0,44 & 0,53 & 0,25 & 0,55 & 0,29 & 0,42 & 0,34 & 0,37 \\
\hline Jarociński & 0,69 & 0,58 & 0,32 & 0,37 & 0,40 & 0,48 & 0,30 & 0,44 & 0,39 & 0,40 & 0,36 & 0,35 \\
\hline Kaliski & 0,51 & 0,66 & 0,25 & 0,35 & 0,36 & 0,49 & 0,31 & 0,67 & 0,18 & 0,38 & 0,23 & 0,51 \\
\hline Kalisz & 0,46 & 0,43 & 0,21 & 0,26 & 0,41 & 0,45 & 0,41 & 0,34 & 0,52 & 0,51 & 0,34 & 0,47 \\
\hline Kępiński & 0,79 & 0,46 & 0,24 & 0,45 & 0,37 & 0,50 & 0,33 & 0,56 & 0,35 & 0,47 & 0,24 & 0,45 \\
\hline Kolski & 0,54 & 0,46 & 0,22 & 0,22 & 0,37 & 0,40 & 0,41 & 0,52 & 0,28 & 0,41 & 0,31 & 0,36 \\
\hline Konin & 0,38 & 0,32 & 0,23 & 0,14 & 0,27 & 0,36 & 0,50 & 0,38 & 0,50 & 0,39 & 0,41 & 0,48 \\
\hline Koniński & 0,45 & 0,55 & 0,25 & 0,38 & 0,35 & 0,42 & 0,40 & 0,22 & 0,21 & 0,37 & 0,28 & 0,32 \\
\hline
\end{tabular}


Tabela 3, cd.

\begin{tabular}{|c|c|c|c|c|c|c|c|c|c|c|c|c|}
\hline 1 & 2 & 3 & 4 & 5 & 6 & 7 & 8 & 9 & 10 & 11 & 12 & 13 \\
\hline Kościański & 0,74 & 0,47 & 0,19 & 0,21 & 0,49 & 0,48 & 0,36 & 0,57 & 0,30 & 0,40 & 0,32 & 0,49 \\
\hline Krotoszyński & 0,78 & 0,52 & 0,35 & 0,32 & 0,43 & 0,42 & 0,35 & 0,54 & 0,34 & 0,41 & 0,38 & 0,40 \\
\hline Leszczyński & 0,78 & 0,40 & 0,32 & 0,37 & 0,36 & 0,43 & 0,50 & 0,60 & 0,29 & 0,39 & 0,32 & 0,31 \\
\hline Leszno & 0,53 & 0,37 & 0,48 & 0,37 & 0,43 & 0,46 & 0,32 & 0,31 & 0,61 & 0,43 & 0,55 & 0,38 \\
\hline Międzychodzki & 0,75 & 0,42 & 0,30 & 0,38 & 0,40 & 0,41 & 0,49 & 0,43 & 0,19 & 0,43 & 0,23 & 0,34 \\
\hline Nowotomyski & 0,83 & 0,47 & 0,33 & 0,33 & 0,34 & 0,46 & 0,47 & 0,52 & 0,36 & 0,41 & 0,31 & 0,39 \\
\hline Obornicki & 0,77 & 0,55 & 0,18 & 0,25 & 0,33 & 0,45 & 0,45 & 0,51 & 0,36 & 0,31 & 0,31 & 0,47 \\
\hline Ostrowski & 0,66 & 0,54 & 0,30 & 0,30 & 0,47 & 0,49 & 0,38 & 0,55 & 0,42 & 0,41 & 0,35 & 0,49 \\
\hline Ostrzeszowski & 0,75 & 0,51 & 0,28 & 0,39 & 0,41 & 0,42 & 0,39 & 0,62 & 0,34 & 0,37 & 0,31 & 0,43 \\
\hline Pilski & 0,65 & 0,44 & 0,25 & 0,22 & 0,43 & 0,40 & 0,40 & 0,22 & 0,42 & 0,41 & 0,31 & 0,36 \\
\hline Pleszewski & 0,73 & 0,50 & 0,33 & 0,45 & 0,53 & 0,49 & 0,31 & 0,69 & 0,32 & 0,48 & 0,43 & 0,41 \\
\hline Poznań & 0,27 & 0,36 & 0,41 & 0,33 & 0,51 & 0,43 & 0,58 & 0,41 & 0,47 & 0,50 & 0,53 & 0,38 \\
\hline Poznański & 0,56 & 0,33 & 0,30 & 0,40 & 0,41 & 0,48 & 0,55 & 0,35 & 0,52 & 0,46 & 0,38 & 0,34 \\
\hline Rawicki & 0,70 & 0,38 & 0,16 & 0,33 & 0,39 & 0,41 & 0,35 & 0,28 & 0,30 & 0,31 & 0,25 & 0,36 \\
\hline Słupecki & 0,57 & 0,49 & 0,30 & 0,33 & 0,41 & 0,44 & 0,32 & 0,48 & 0,27 & 0,35 & 0,32 & 0,36 \\
\hline Szamotulski & 0,77 & 0,47 & 0,30 & 0,37 & 0,40 & 0,42 & 0,55 & 0,48 & 0,38 & 0,43 & 0,34 & 0,39 \\
\hline Średzki & 0,40 & 0,59 & 0,27 & 0,25 & 0,43 & 0,48 & 0,35 & 0,51 & 0,44 & 0,44 & 0,25 & 0,49 \\
\hline Śremski & 0,76 & 0,50 & 0,17 & 0,31 & 0,36 & 0,42 & 0,33 & 0,53 & 0,41 & 0,44 & 0,30 & 0,41 \\
\hline Turecki & 0,59 & 0,51 & 0,28 & 0,35 & 0,33 & 0,42 & 0,44 & 0,35 & 0,22 & 0,32 & 0,26 & 0,33 \\
\hline Wągrowiecki & 0,64 & 0,60 & 0,18 & 0,13 & 0,31 & 0,37 & 0,37 & 0,66 & 0,30 & 0,41 & 0,29 & 0,45 \\
\hline Wolsztyński & 0,76 & 0,56 & 0,25 & 0,31 & 0,46 & 0,50 & 0,34 & 0,31 & 0,32 & 0,33 & 0,37 & 0,51 \\
\hline Wrzesiński & 0,65 & 0,51 & 0,20 & 0,17 & 0,40 & 0,43 & 0,40 & 0,85 & 0,44 & 0,41 & 0,35 & 0,41 \\
\hline Złotowski & 0,62 & 0,48 & 0,17 & 0,32 & 0,30 & 0,45 & 0,33 & 0,32 & 0,21 & 0,32 & 0,23 & 0,41 \\
\hline
\end{tabular}

Źródło: opracowanie własne na podstawie przeprowadzonego badania.

W ostatnim etapie procedury badawczej wyznaczono dla każdego powiatu miernik syntetyczny będący wskaźnikiem poziomu rozwoju w danym powiecie. Miernik syntetyczny obliczono na podstawie poniższego wzoru [Runge 2007]:

$$
v_{i}=1-\frac{d_{i 0}}{d_{0}},
$$

gdzie: $v_{i}$ - syntetyczny wskaźnik poziomu rozwoju dla powiatu $i ; d_{i 0}$ - odległość powiatu $i$ od wzorca rozwoju; $d_{0}$ - odległość wzorca od antywzorca rozwoju.

Syntetyczny wskaźnik poziomu rozwoju przyjmuje wartości od 0 do 1 , przy czym im wyższa jego wartość, tym wyższy poziom rozwoju badanego zjawiska. Na podstawie obliczonych wskaźników syntetycznych badane powiaty województwa wielkopolskiego podzielono na trzy grupy: o niskim, przeciętnym i wysokim poziomie rozwoju. Z kolei biorąc pod uwagę badanie w ujęciu dynamicznym, powiaty, w których wskaźnik syntetyczny przyjmował najwyższe wartości, zaklasyfikowano do grupy o dużej zmianie poziomu rozwoju danego zjawiska, a powiaty, w których wskaźnik syntetyczny przyjmował najniższe wartości, zaklasyfikowano do grupy o niewielkiej zmianie poziomu rozwoju tego zjawiska. 


\section{Wnioski z przeprowadzonego badania - czynniki rozwoju}

W wyniku przeprowadzonej procedury badawczej ukazano zróżnicowanie przestrzenne powiatów województwa wielkopolskiego ze względu na poziom rozwoju społeczno-gospodarczego oraz pięciu kapitałów będących czynnikami rozwoju regionalnego (rys. 1). W badanej grupie wartość miernika syntetycznego, wyrażającego poziom rozwoju społeczno-gospodarczego w 2015 roku, wahała się od 0,23 do 0,55. Z kolei wartość tego miernika wyrażającego zmianę poziomu rozwoju społeczno-gospodarczego w latach 2007-2015 wahała się od 0,31 do 0,52 (tabela 3). Podobne zróżnicowanie odnotowano w przypadku kapitału ludzkiego (0,27-0,83 dla 2015 roku oraz 0,32-0,66 dla zmiany w latach 2007-2015), kapitału społecznego (odpowiednio: 0,14-0,48 oraz 0,13-0,45), kapitału materialnego (odpowiednio: 0,27$-0,53$ oraz $0,32-0,53$ ), kapitału finansowego (odpowiednio: $0,25-0,58$ oraz $0,22-0,85$ ) oraz innowacyjności (odpowiednio: 0,18-0,61 oraz 0,31-0,51).

Ze względu na poziom rozwoju kapitału ludzkiego najwyższą wartość wskaźnika syntetycznego w 2015 roku odnotowano w powiecie nowotomyskim, a najniższą - w Poznaniu. Do grupy powiatów o wysokim poziomie rozwoju kapitału ludzkiego w 2015 roku zaliczono jednostki położone na zachodzie i południowym zachodzie województwa oraz $\mathrm{w}$ południowej części regionu. $\mathrm{Z}$ kolei do grupy powiatów o niskim poziomie rozwoju kapitału ludzkiego w 2015 roku zaliczono wszystkie miasta na prawach powiatu oraz powiaty: poznański, średzki i chodzieski, a także jednostki położone we wschodniej części Wielkopolski. Wyniki badań są sprzeczne z powszechną opinią dotyczącą poziomu rozwoju kapitału ludzkiego, zgodnie z którą najlepsza jakość tego kapitału występuje w centrum regionu (Poznań i powiat poznański) oraz $\mathrm{w}$ pozostałych dużych miastach. O niskiej pozycji dużych ośrodków miejskich przesądziły: bardzo wysoki (ponad 20\%) udział osób w wieku poprodukcyjnym w ludności ogółem oraz relatywnie wysoki odsetek bezrobotnych z wykształceniem wyższym w ogólnej liczbie bezrobotnych (wynoszący chociażby w Poznaniu 25,7\%). Natomiast o wysokiej pozycji w rankingu mniejszych powiatów zdecydował relatywnie niski udział bezrobotnych z wykształceniem wyższym w ogólnej liczbie bezrobotnych oraz fakt, iż wyższą zdawalność matur w województwie wielkopolskim odnotowuje się w średnich i małych miastach. Z kolei biorąc pod uwagę badanie przeprowadzone w ujęciu dynamicznym, największą zmianę poziomu rozwoju kapitału ludzkiego w latach 2007-2015 zaobserwowano w powiecie kaliskim, a najmniejszą - w Koninie. Do grupy powiatów o niewielkiej zmianie poziomu rozwoju tego kapitału ludzkiego zaliczono ponownie wszystkie miasta na prawach powiatu (Poznań, Konin, Leszno i Kalisz). O słabszej pozycji dużych miast w badaniu przeważyły: wysoki (ponad 10\%) wzrost wskaźnika obciążenia demograficznego mierzonego liczbą ludności w wieku nieprodukcyjnym na 100 osób w wieku produkcyjnym, wysoki (ponad 30\%) wzrost liczby ludności w wieku poprodukcyjnym na 100 osób w wieku przedprodukcyjnym oraz niewielki wzrost (a w przypadku kilku powiatów nawet spadek) poziomu zdawalności matur. Na- 

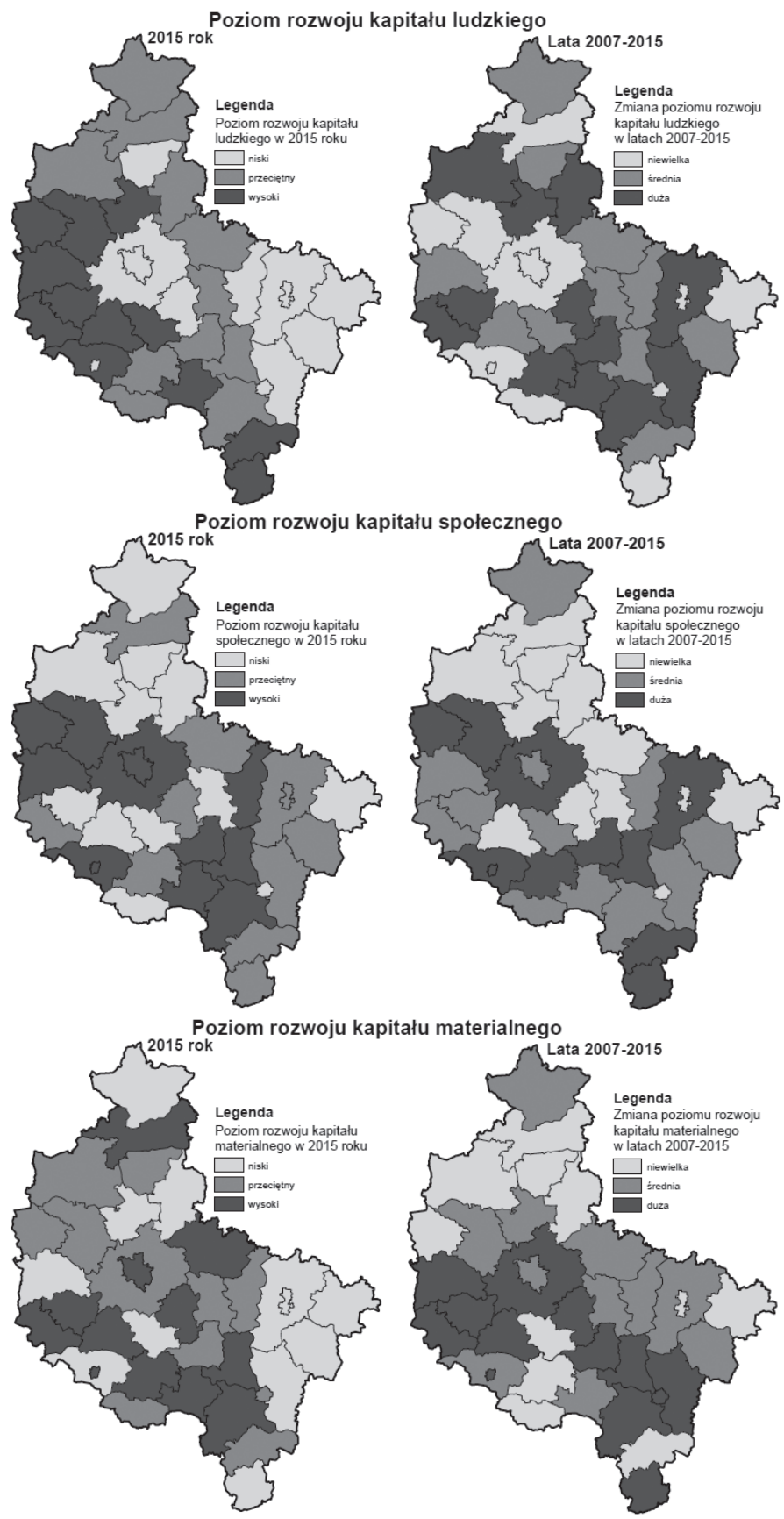

Rys. 1. Zróżnicowanie przestrzenne poziomu rozwoju społeczno-gospodarczego i jego aspektów Źródło: opracowanie własne na podstawie przeprowadzonego badania. 

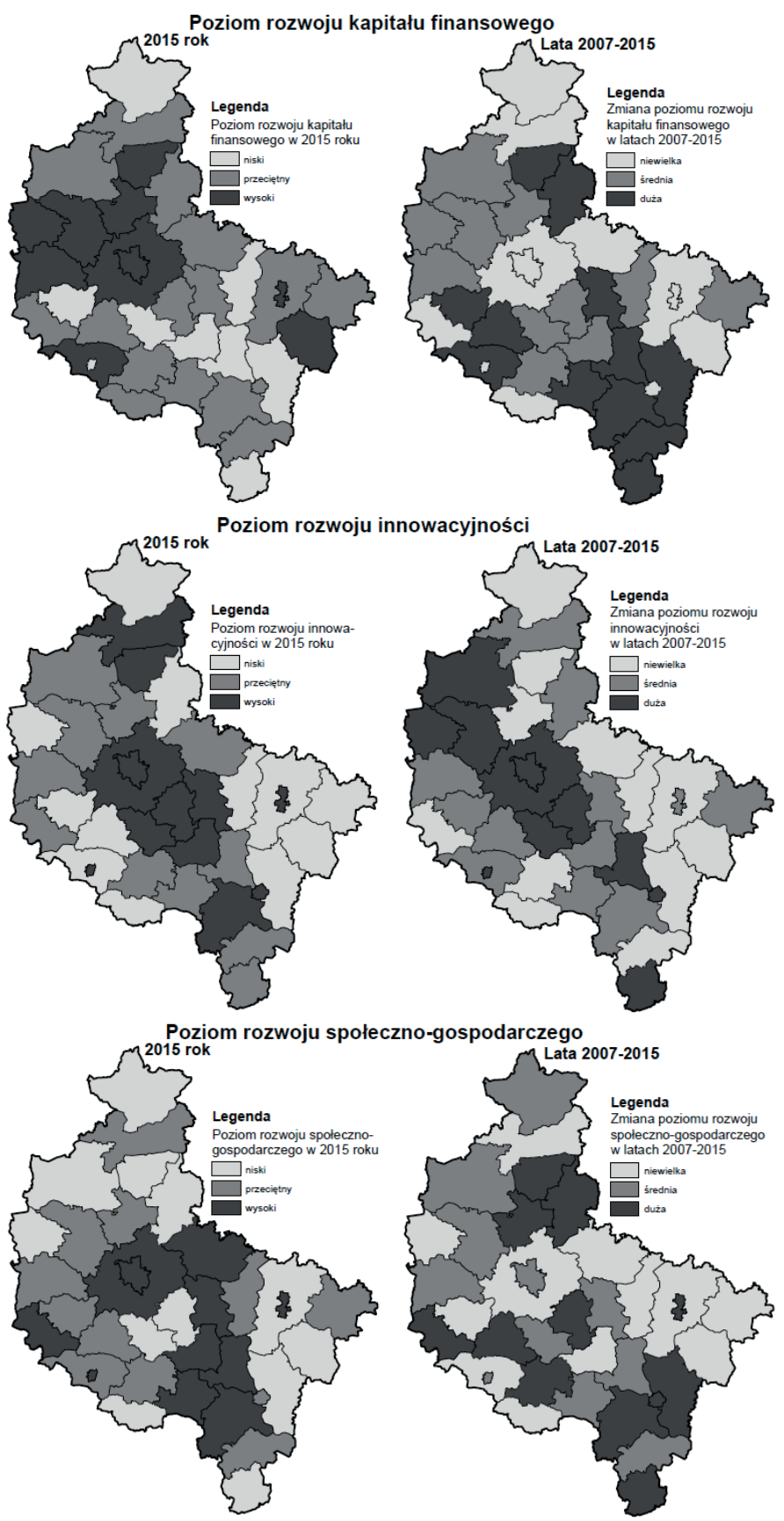

w województwie wielkopolskim w układzie powiatów 
tomiast o wysokiej pozycji $\mathrm{w}$ rankingu mniejszych powiatów przesądziły: duża poprawa zdawalności matur (w powiecie średzkim nawet o około 40\%) oraz relatywnie duży spadek odsetka bezrobotnych poniżej 25. roku życia w ogólnej liczbie bezrobotnych.

Ze względu na poziom rozwoju kapitału społecznego najwyższą wartość wskaźnika syntetycznego w 2015 roku odnotowano w Lesznie oraz Poznaniu, a najniższą - w powiatach: grodziskim i rawickim. O wysokiej pozycji ośrodków miejskich oraz powiatów w środkowej i zachodniej części województwa przesądziły: wysoka frekwencja w wyborach parlamentarnych oraz duża liczba organizacji społecznych na 1000 mieszkańców. Natomiast o niskiej pozycji w rankingu mniejszych powiatów zdecydowała relatywnie mała liczba organizacji społecznych oraz członków kół i klubów na 1000 mieszkańców. Z kolei biorąc pod uwagę badanie przeprowadzone w ujęciu dynamicznym, największą zmianę poziomu rozwoju kapitału społecznego w latach 2007-2015 zaobserwowano w powiecie kępińskim i pleszewskim, a najmniejszą - w powiecie wągrowieckim i Koninie oraz powiatach północnej części województwa wielkopolskiego. Na słabszą pozycję powiatów w badaniu wpłynęły: spadek frekwencji w wyborach parlamentarnych i samorządowych oraz spadek liczby osób fizycznych prowadzących działalność gospodarczą na 1000 mieszkańców. Natomiast o wysokiej pozycji w rankingu powiatów przesądziły: wzrost frekwencji w wyborach oraz znaczny (nawet 11-procentowy w przypadku powiatu pleszewskiego) wzrost liczby członków kół i klubów na 1000 mieszkańców.

Biorąc pod uwagę poziom rozwoju kapitału materialnego najwyższą wartość wskaźnika syntetycznego w 2015 roku odnotowano w powiecie pleszewskim, Poznaniu i powiecie kościańskim, a najniższą - w Koninie oraz powiatach: złotowskim i wągrowieckim. Do grupy powiatów o wysokim poziomie rozwoju kapitału materialnego w 2015 roku zaliczono jednostki położone przede wszystkim w południowo-zachodniej części województwa. Z kolei do grupy powiatów o niskim poziomie rozwoju kapitału materialnego w 2015 roku zaliczono powiaty położone we wschodniej części Wielkopolski. O wysokiej pozycji w rankingu wskazanych powiatów zdecydowała bardzo dobrze rozwinięta infrastruktura techniczna oraz duża liczba lekarzy na 10000 mieszkańców. Natomiast o niskiej pozycji poszczególnych jednostek przesądziły: braki w rozwoju infrastruktury technicznej oraz niski poziom opieki zdrowotnej. Z kolei biorąc pod uwagę badanie przeprowadzone w ujęciu dynamicznym, największą zmianę poziomu rozwoju kapitału ludzkiego w latach 2007-2015 zaobserwowano w powiatach: grodziskim, kępińskim i wolsztyńskim, a najmniejszą - w Koninie oraz powiecie gostyńskim. O wysokiej pozycji w rankingu poszczególnych powiatów przesądziły: poprawa stanu infrastruktury drogowej oraz sieciowej, a także objęcie opieką żłobkową większej liczby dzieci. O słabszej pozycji powiatów przesądziły: wzrost ilości wytwarzanych odpadów, brak rozwoju infrastruktury drogowej oraz brak poprawy dostępu do lekarzy i łóżek szpitalnych.

Ze względu na poziom rozwoju kapitału finansowego najwyższą wartość wskaźnika syntetycznego w 2015 roku odnotowano w Poznaniu i powiecie szamo- 
tulskim, a najniższą - w powiatach: grodziskim i jarocińskim. O wysokiej pozycji poszczególnych powiatów przesądziły: wysokość przeciętnego wynagrodzenia oraz wartość dochodów własnych JST per capita. Natomiast o niskiej pozycji w rankingu wskazanych powiatów zdecydowały stosunkowo niskie wynagrodzenia ludności oraz niewielka nadwyżka dochodów nad wydatkami budżetowymi. Z kolei biorąc pod uwagę badanie przeprowadzone w ujęciu dynamicznym, największą zmianę poziomu rozwoju kapitału finansowego w latach 2007-2015 zaobserwowano w powiecie wrzesińskim i pleszewskim, a najmniejszą - w powiecie pilskim i konińskim. O słabszej pozycji powiatów w badaniu zadecydowały: nieznaczny wzrost przeciętnych wynagrodzeń oraz wpływów z podatku od nieruchomości. Natomiast o wysokiej pozycji w rankingu powiatów przesądziły: najwyższy w badanym okresie wzrost przeciętnych wynagrodzeń, a także relatywnie duży wzrost dochodów własnych na mieszkańca oraz wydatków majątkowych na mieszkańca.

Z kolei biorąc pod uwagę poziom innowacyjności, najwyższą wartość wskaźnika syntetycznego w 2015 roku odnotowano w miastach na prawach powiatu oraz $\mathrm{w}$ powiatach położonych $\mathrm{w}$ środkowej części województwa: poznańskim, wrzesińskim, średzkim, śremskim i jarocińskim, a najniższą - w powiatach: kaliskim, konińskim, międzychodzkim i złotowskim. O wysokiej pozycji poszczególnych powiatów przesądziły: duża liczba mikroprzedsiębiorstw na 1000 mieszkańców oraz wysoki udział podmiotów prowadzących działalność finansową w podmiotach gospodarczych ogółem. Z kolei biorąc pod uwagę badanie przeprowadzone $\mathrm{w}$ ujęciu dynamicznym, największą zmianę poziomu rozwoju innowacyjności w latach 2007-2015 zaobserwowano w Kaliszu i Poznaniu, a najmniejszą - w powiecie obornickim i rawickim. O pozycji powiatów w badaniu w ujęciu dynamicznym przesądziły: udział podmiotów sektora prywatnego w podmiotach gospodarczych ogółem, udział spółek zagranicznych w podmiotach gospodarczych ogółem, liczba mikroprzedsiębiorstw na 1000 mieszkańców oraz udział podmiotów prowadzących działalność usługową, finansową i edukacyjną w podmiotach gospodarczych ogótem.

\section{Zakończenie - poziom rozwoju społeczno-gospodarczego}

Podsumowując wyniki przeprowadzonej analizy poziomu rozwoju społeczno-gospodarczego poszczególnych powiatów województwa wielkopolskiego, można wskazać następujące wnioski. Poziom tego rozwoju w 2015 roku określono na podstawie sześciu cech: zdawalności matur, liczby członków kół, klubów i grup artystycznych na 1000 mieszkańców, udziału mikroprzedsiębiorstw we wszystkich podmiotach gospodarczych, liczby zwiedzających muzea na 10000 mieszkańców, dostępności lekarzy oraz udziału podmiotów sektora prywatnego w podmiotach gospodarczych ogółem. Najwyższą wartość wskaźnika syntetycznego odnotowano w Lesznie, a następnie: Poznaniu, powiecie gnieźnieńskim i pleszewskim. Postawiona we wstępie artykułu hipoteza została zatem w części potwierdzona. Z kolei 
najniższą wartość wskaźnika zaobserwowano w powiecie kaliskim, a następnie w powiatach: złotowskim, międzychodzkim i kępińskim. Poziom rozwoju społecznogospodarczego jest wypadkową rozwoju poszczególnych kapitałów, a powiaty z najwyższą wartością wskaźnika syntetycznego pojawiały się również wysoko w rankingach poszczególnych kapitałów i odwrotnie. Z kolei biorąc pod uwagę badanie przeprowadzone $\mathrm{w}$ ujęciu dynamicznym, największą zmianę poziomu rozwoju społeczno-gospodarczego latach 2007-2015 zaobserwowano w powiecie chodzieskim, a następnie w powiatach: wolsztyńskim, kaliskim i kościańskim, a najmniejszą - w powiecie leszczyńskim, a następnie w powiatach: konińskim, tureckim i międzychodzkim. Zmianę poziom rozwoju społeczno-gospodarczego określono na podstawie 11 cech: 4 z zakresu kapitału ludzkiego (udział ludności w wieku poprodukcyjnym w ludności ogółem, zdawalność egzaminów maturalnych w liceach ogólnokształcących, udział bezrobotnych z wyższym wykształceniem w ogólnej liczbie bezrobotnych oraz udział bezrobotnych poniżej 25 roku życia w ogólnej liczbie bezrobotnych), $3 \mathrm{z}$ zakresu kapitału materialnego (udział korzystających z oczyszczalni ścieków w ogólnej liczbie ludności, księgozbiór bibliotek na 1000 mieszkańców, zwiedzający muzea na 10000 mieszkańców), 2 z zakresu kapitału finansowego (dochody z podatku od nieruchomości per capita, wydatki na obsługę długu publicznego JST per capita) i 2 z zakresu innowacyjności (udział podmiotów prowadzących działalność usługową w podmiotach gospodarczych ogółem, udział pracujących w usługach w pracujących ogółem). Warto zwrócić uwagę na fakt, iż powiatami o wysokim poziomie rozwoju społeczno-gospodarczego są z reguły te jednostki, w których zaszła największa zmiana poziomu tego rozwoju w latach 2007-2015 (wyjątkiem są powiaty: poznański gnieźnieński, jarociński i leszczyński). Z kolei w powiatach o niskim poziomie rozwoju społeczno-gospodarczego $\mathrm{w}$ 2015 roku dokonała się najmniejsza zmiana tego rozwoju w latach 2007-2015 (dotyczy to chociażby powiatów wschodniej części województwa). Można zatem stwierdzić, iż z jednej strony - o bieżącym poziomie rozwoju społeczno-gospodarczego poszczególnych powiatów $\mathrm{w}$ dużej mierze decydują działania podejmowane $\mathrm{w}$ ostatnich dziewięciu latach, czyli w okresie członkostwa Polski w Unii Europejskiej, a z drugiej strony - następują coraz większe dysproporcje w rozwoju społeczno-gospodarczym powiatów województwa, gdyż w największym stopniu wzrósł poziom rozwoju społeczno-gospodarczego w silnych gospodarczo powiatach (np. w miastach na prawach powiatu), a w najmniejszym stopniu - w relatywnie słabiej rozwiniętych powiatach (np. w tych, które położone są we wschodniej części województwa wielkopolskiego). 


\section{Literatura}

Barro R., Sala-i-Martin X., 2004, Economic Growth, MIT Press, Boston.

Churski P., 2008, Czynniki rozwoju regionalnego i polityka regionalna w Polsce w okresie integracji z Unia Europejska, Wydawnictwo Naukowe UAM, Poznań.

Frank I.E., Todeschini R., 1994, The Data Analysis Handbook, Elsevier Science, Amsterdam.

Grosse T.G., 2004, Poland and the EU New Cohesion Policy, Instytut Spraw Publicznych, Warszawa.

GUS, Bank Danych Lokalnych, http://stat.gov.pl/bdl (23.03.2017).

Iyer S., Kitson M., Toh B., 2005, Social capital, economic growth and regional development, Regional Studies, no. 8, s. 1015-1040.

Koop G., 2014, Wprowadzenie do ekonometrii, Wolters Kluwer, Warszawa.

Maddala G.S., 2013, Ekonometria, Wydawnictwo Naukowe PWN, Warszawa.

Nowak E., 1990, Metody taksonomiczne w klasyfikacji obiektów spoleczno-gospodarczych, Warszawa.

Omiotek Z., Wójcik W., 2014, Zastosowanie metody Hellwiga do redukcji wymiaru przestrzeni cech obrazów USG tarczycy, Informatyka, Automatyka, Pomiary w Gospodarce i Ochronie Środowiska, nr 3, s. 14-17.

Runge J., 2007, Metody badań w geografii społeczno-ekonomicznej, Wydawnictwo Uniwersytetu Śląskiego, Katowice.

Spychała M., 2016, Zmiany w strukturze oraz intensywności pomocy regionalnej w Polsce, Nierówności Społeczne a Wzrost Gospodarczy, nr 4, s. 278-289.

Stiglitz J.E., 2004, Globalizacja, Wydawnictwo Naukowe PWN, Warszawa. 